\title{
Rancang Bangun Sistem IT-Helpdesk Untuk Maintenance dan Tutorial Aplikasi Simplebiz Menggunakan Metode Forward Chaining dan Certainty Factor
}

\author{
I Gusti Ngurah Wira Partha ${ }^{1}$, Rukmi Sari Hartati ${ }^{2}$, Lie Jasa ${ }^{3}$ \\ [Submission:03-07-2021, Accepted: 13-08-2021]
}

\begin{abstract}
Simplebiz application is a general term for 20 desktop-based business applications that have been built and developed by PT. Bamboomedia Cipta Persada. Until now, the number of users of the simplebiz application throughout Indonesia has reached 10,508 people, while the number of technical support in the IT-helpdesk division at PT. Bamboomedia Cipta Persada only 2 people. Based on these problems, it is necessary to have a system that can be used by users of the simplebiz application to obtain solutions to the problems they face, as if they were consulting directly with a technical support, so that it is expected to be able to help technical support in the IT-helpdesk division at PT. Bamboomedia Cipta Persada in handling and reducing the number of complaints received either face-to-face, by telephone, SMS or via chat applications. In this research, an IT-helpdesk system for maintenance and simplebiz application tutorial has been successfully designed and built using forward chaining and certainty factor Methods. The percentage of confidence from the solution generated by the system to the problems faced by simplebiz application users is $\mathbf{8 9 \%}$ and the level of confidence from the output to the contribution of solving the problem is ALMOST SURE.
\end{abstract}

Intisari- Aplikasi simplebiz merupakan sebutan umum dari 20 aplikasi bisnis berbasis desktop yang telah dibangun dan dikembangkan oleh PT. Bamboomedia Cipta Persada. Sampai saat ini jumlah pengguna dari aplikasi simplebiz di seluruh Indonesia telah mencapai 10.508 orang, sedangkan jumlah technical support pada divisi IT-helpdesk di PT. Bamboomedia Cipta Persada hanya 2 orang. Berdasarkan dari permasalahan tersebut, maka diperlukan sebuah sistem yang dapat digunakan oleh pengguna aplikasi simplebiz untuk memperoleh solusi dari kendala yang dialami layaknya berkonsultasi secara langsung dengan seorang technical support, sehingga diharapkan mampu membantu para technical support pada divisi IT-helpdesk di PT. Bamboomedia Cipta Persada dalam menangani sekaligus mengurangi jumlah pengaduan yang diterima baik secara bertatap muka, melalui telepon, SMS, maupun melalui aplikasi chat. Pada penelitian ini telah berhasil dirancang dan dibangun sebuah sistem IT-helpdesk untuk maintenance dan tutorial aplikasi simplebiz menggunakan metode forward chaining dan certainty factor, dimana melalui hasil uji coba yang telah dilakukan pada sistem, menghasilkan persentase keyakinan dari solusi yang dihasilkan oleh sistem terhadap masalah yang dihadapi pengguna aplikasi simplebiz sebesar $89 \%$ dan tingkat

\footnotetext{
${ }^{1}$ Mahasiswa, Magister Teknik Elektro Universitas Udayana, Gedung Pacasarjana Universitas Udayana Jl. PB Sudirman Denpasar-Bali, Kode Pos: 80232; (tlp/fax: 0361-239599; e-mail: ignwirapartha@gmail.com)

${ }^{2,3}$ Dosen, Magister Teknik Elektro Universitas Udayana, Gedung Pacasarjana Universitas Udayana Jl. PB Sudirman Denpasar-Bali, Kode Pos: 80232; (tlp/fax: 0361-239599)
}

keyakinan dari output terhadap kontribusi penyelesaian masalah tersebut adalah HAMPIR PASTI.

Kata Kunci- Sistem Informasi, Sistem Pakar, Sistem Berbasis Pengetahuan, Artificial Intelligence, Technical Support, ITHelpdesk, Forward Chaining, Certainty Factor.

\section{Pendahuluan}

Pada perkembangan teknologi seperti saat ini, helpdesk memiliki peranan yang sangat penting dalam menjamin ketersediaan dan kualitas layanan teknologi informasi (IT) pada suatu organisasi. Helpdesk sebagai Single Point of Contact (SPOC) menjadi fasilitas komunikasi antara pelanggan atau pengguna dengan tim pendukung di organisasi penyedia produk atau jasa [1]. Selain itu, Helpdesk juga merupakan center point sebuah organisasi yang membantu menangani kebutuhan pelanggan atau pengguna terkait dengan pertanyaan, pelayanan, dukungan teknis, atau keluhan terhadap produk dan jasa tertentu [2].

PT. Bamboomedia Cipta Persada atau yang lebih populer dengan nama Bamboomedia merupakan perusahaan yang bergerak dalam bidang pengembangan aplikasi perangkat lunak. Bamboomedia beralamat di Jl. Merdeka No. 45 Renon Denpasar, Bali. Bamboomedia memiliki beberapa divisi, salah satunya yaitu divisi IT-helpdesk, dimana di dalam divisi ini hanya terdapat dua orang technical support. Divisi IThelpdesk memiliki berbagai macam tugas dan kewajiban, dimana salah satunya yaitu untuk menerima dan menyelesaikan berbagai pengaduan masalah atau kendala teknis dalam penerapan, penggunaan, pemeliharaan dan konfigurasi aplikasi simplebiz.

Aplikasi simplebiz merupakan sebutan dari kumpulan aplikasi bisnis berbasis desktop yang telah dibangun dan dikembangkan oleh PT. Bamboomedia Cipta Persada, diantaranya yaitu Akuntansi 3.0, Akademik Sekolah 3.0, Customer Care 2.0, Hospital Express, Just POS, Keuangan Keluarga 3.0, Klinik 2.0, Kuliner POS 3.0, Payroll 4.0, Penjualan \& Stok Barang Small Business, Penjualan \& Stok Barang Medium Business, Penginapan 2.0 , Penyewaan 2.0, Perpustakaan 3.0, Praktek Dokter 3.0, Simpan Pinjam 3.0, Smart Teacher 2.0, Longlife Business Basic, Longlife Business Premium, Longlife Business Ultimate.

Sampai saat ini jumlah pengguna dari aplikasi simplebiz di seluruh Indonesia mencapai 10.508 orang. Berdasarkan dari hal tersebut, rata-rata dalam seharinya seorang technical support dapat menangani 60 pengaduan kendala baik secara bertatap muka, melalui telepon, SMS, maupun melalui aplikasi chat dan waktu yang dibutuhkan oleh seorang technical support untuk dapat menyelesaikan sebuah kendala 
dari pengaduan tersebut adalah sekitar 20 menit, oleh karena itu tidak semua kendala yang diadukan pada hari tersebut dapat diselesaikan oleh para technical support.

Dengan banyaknya jumlah pengaduan kendala dari pengguna aplikasi setiap harinya dan dengan terbatasnya jumlah technical support yang terdapat di divisi IT-helpdesk, mengakibatkan banyak pengaduan dari pengguna aplikasi yang tidak tertangani dengan baik karena jumlah kendala yang diadukan oleh pengguna aplikasi tidak sebanding dengan sumber daya manusia yang tersedia. Hal inilah yang menyebabkan para technical support sering mengalami kesulitan. Jika situasi seperti ini tetap berlanjut, maka hal ini tidak hanya akan berdampak pada kinerja dari para technical support, namun juga akan berdampak pada kekecewaan dan ketidakpuasan dari para pengguna aplikasi simplebiz, sehingga secara otomatis akan memberikan kerugian pada perusahaan.

Berdasarkan dari permasalahan tersebut, maka diperlukan suatu sistem IT-helpdesk yang dapat membantu para technical support dalam menangani kendala yang dialami oleh para pengguna aplikasi simplebiz sekaligus mengurangi jumlah pengaduan yang diterima baik secara bertatap muka, melalui telepon, SMS, maupun melalui aplikasi chat, dimana sistem tersebut diharapkan dapat digunakan oleh para pengguna aplikasi simplebiz untuk berkonsultasi dan memperoleh solusi layaknya berkonsultasi langsung dengan seorang technical support, sehingga para pengguna aplikasi simplebiz dapat mengatasi kendala yang dialaminya secara mandiri.

Penelitian ini akan mengkombinasikan metode forward chaining dan certainty factor, dimana metode forward chaining merupakan sebuah proses penelusuran yang dimulai dengan menampilkan kumpulan data atau fakta yang meyakinkan untuk menuju kesimpulan akhir [3], dan metode certainty factor merupakan suatu metode yang digunakan untuk membuktikan ketidakpastian pemikiran seorang pakar, dimana untuk mengakomodasi hal tersebut seseorang biasanya menggunakan metode certainty factor untuk menggambarkan tingkat keyakinan pakar terhadap masalah yang sedang dihadapi [4].

Sesuai dengan uraian diatas, maka metode forward chaining dan certainty factor akan digunakan dan dikombinasikan pada sistem IT-helpdesk ini dengan proses, dimana metode forward chaining akan digunakan untuk menelusuri ciri-ciri kendala yang dialami oleh pengguna aplikasi simplebiz yang akan ditampilkan dalam bentuk pilihan-pilihan, sehingga sistem dapat memberikan solusi untuk kendala tersebut sesuai dengan basis pengetahuan (rule base) dari technical support, kemudian metode certainty factor akan digunakan untuk mendapatkan nilai keyakinan terhadap solusi yang telah diberikan oleh sistem. Sistem IThelpdesk ini akan dirancang berbasis responsive website untuk memudahkan para pengguna aplikasi simplebiz untuk mengakses sistem ini baik melalui desktop maupun mobile. Berdasarkan hal tersebut, maka tujuan dari penelitian ini adalah melakukan Rancang bangun sistem IT-helpdesk untuk maintenance dan tutorial aplikasi simplebiz menggunakan metode forward chaining dan certainty factor.

\section{KAJIAN LITERATUR}

\section{A. Tinjauan Muktahir}

Beberapa penelitian telah dilakukan terkait upaya dalam merancang sistem helpdesk dan menerapkan metode forward chaining, certainty factor, maupun kombinasi dari metode forward chaining dan certainty factor. Penelitian tersebut antara lain.

- Pada penelitian [5] membahas mengenai rancang bangun aplikasi helpdesk menggunakan pendekatan knowledge management system. Hasil penelitian ini menunjukan bahwa knowledge management system di dalam aplikasi helpdesk dapat membantu karyawan untuk memperoleh informasi dan pengetahuan mengenai prosedur perbaikan kerusakan fasilitas ruangan tanpa perlu menghubungi maupun berkonsultasi langsung dengan teknisi.

- Pada penelitian [6] membahas mengenai perancangan sistem IT-helpdesk, dimana sistem IT-helpdesk ini dapat dimanfaatkan oleh konsumen dan manajemen perusahaan dalam melacak status pelayanan, memantau, dan mengevaluasi kinerja para teknisi di divisi IThelpdesk.

- Pada penelitian [7] membahas mengenai perancangan aplikasi helpdesk menggunakan postgreSQL, framework laravel, dan metode Rapid Application Management (RAD), dimana berdasarkan hasil kuisioner menunjukkan antara 60\% sampai dengan 80\% setuju bahwa sistem helpdesk yang dirancang dan dibangun sudah sesuai dengan kebutuhan perusahaan.

- Pada penelitian [8] membahas mengenai perancangan sistem pakar untuk mendiagnosa hama pada tumbuhan anggrek hitam kalimantan menggunakan metode kombinasi forward chaining dan certainty factor. Hasil dari penelitian ini menunjukkan bahwa tingkat keyakinan pakar terhadap hasil diagnosa sistem adalah sebesar 93,0736\%, hal tersebut membuktikan bahwa kedua metode ini sangat cocok untuk diterapkan dan dikombinasikan.

- Pada penelitian [9] membahas mengenai analisis dan perancangan sistem pakar untuk mendiagnosa hama dan penyakit pada tanaman padi menggunakan dua metode yaitu forward chaining dan certainty factor. Metode forward chaining digunakan untuk mencari fakta-fakta gejala penyakit dari tanaman padi dan metode certainty factor digunakan untuk menentukan tingkat kepercayaan pakar terhadap gejala tersebut. Hasil penelitian ini menunjukkan bahwa tingkat akurasi dari sistem yang dirancang dan dibangun adalah sebesar 73,81\%. Hal membuktikan bahwa metode forward chaining dan certainty factor sangat mungkin diterapkan dan dikombinasikan pada sistem pakar ini karena mampu membantu petani dalam mendiagnosa hama dan penyakit dari tanaman padi dengan sangat baik.

- Pada penelitian [10] membahas mengenai perancangan sistem pakar untuk mendiagnosis penyakit saluran pencernaan pada anak-anak menggunakan kombinasi metode forward chaining dan certainty factor. Hasil penelitian tersebut menunjukkan bahwa sistem yang dirancang dan dibangun memiliki tingkat akurasi sebesar $100 \%$ dengan nilai kepercayaan sebesar $80,5 \%$. 
Hal tersebut menunjukkan bahwa kombinasi metode forward chaining dan certainty factor sangat tepat untuk diimplementasikan karena memberikan hasil yang sangat akurat.

- Pada penelitian [11] menunjukkan bahwa penggunaan dan kombinasi metode forward chaining dan certainty factor sangat cocok digunakan untuk sistem pakar dan sistem berbasis pengetahuan yang prosesnya dimulai dari pengumpulan fakta-fakta hingga memperoleh kesimpulan dan nilai keyakinan dari kesimpulan tersebut. Hal ini telah dibuktikan dari hasil dari penelitian ini, dimana kombinasi metode forward chaining dan certainty factor bisa mencapai tingkat kecocokan sebesar 73,33\%.

- Pada penelitian [12] menunjukkan bahwa kombinasi metode forward chaining dan certainty factor telah memenuhi kriteria berhasil dalam pengujian sistem pakar dan sistem berbasis pengetahuan, karena sangat cocok digunakan pada sistem yang berawal dari pengumpulan premis, yang dilanjutkan proses inferensi, hingga menghasilkan konklusi dan nilai keyakinan pakar yang menunjukkan tingkat kebenaran dan keakuratan sistem. Hal tersebut dibuktikan dari hasil persentase kepastian dan keyakinan dari pengujian pada sistem yang dirancang yaitu sebesar 93,6\%.

- Pada penelitian [13] membahas mengenai perancangan sistem pakar menggunakan kombinasi metode forward chaining dan metode certainty factor untuk mendiagnosa sekaligus memberikan solusi kepada pasien penyakit menular, sehingga pasien dapat seolaholah berkonsultasi secara langsung dengan dokter. Hasil dari penelitian ini menunjukkan bahwa nilai akurasi dari sistem tersebut adalah sebesar $85 \%$.

- Pada penelitian [14] membahas mengenai identifikasi penyakit telinga menggunakan kombinasi metode forward chaining dan certainty factor, dimana hasil penelitian ini menunjukkan bahwa kombinasi dua metode ini dapat memberikan nilai akurasi sebesar $80 \%$.

- Pada penelitian [15] membahas mengenai analisis penerapan metode forward chaining untuk rekomendasi instalasi Local Area Network (LAN) menggunakan pengujian System Usability Scale (SUS), dimana penelitian ini dapat membantu perusahaan dalam memperoleh rekomendasi instalasi jaringan LAN tanpa perlu menyewa teknisi jaringan IT. Terdapat 12 aturan yang dihasilkan untuk dapat memperoleh rekomendasi tersebut pada penelitian ini, kemudian pengujian kebergunaan penelitian ini memperoleh nilai 81 .

Berdasarkan hasil dan kesimpulan dari beberapa penelitian terdahulu tersebut, maka alasan dan pertimbangan penggunaan dan kombinasi metode forward chaining dan certainty factor pada penelitan ini, adalah karena sangat cocok digunakan untuk sistem pakar atau sistem berbasis pengetahuan yang prosesnya dimulai dari pengumpulan data atau fakta, dimana dari data dan fakta tersebut, dicari kesimpulan berupa solusi dari masalah yang dihadapi, lalu mesin inferensi mencari aturan dalam basis pengetahuan (rule base) bahwa premis sudah sesuai dengan data yang ada, kemudian dari aturan terdapat sebuah kesimpulan, dimana I Gusti Ngurah Wira Partha: Rancang Bangun Sistem IT-Helpdesk... kesimpulan tersebut disertai dengan nilai keyakinan pakar yang menunjukkan tingkat kepastian, kebenaran, dan keakuratan dari sistem.

Hal tersebut sangat sesuai dengan alur sistem dari penelitian ini, dimana prosesnya dimulai dari penelusuran dan pengumpulan ciri-ciri kendala yang dialami oleh pengguna aplikasi simplebiz, lalu dari ciri-ciri kendala tersebut akan diperoleh sebuah solusi sesuai dengan basis pengetahuan (rule base) dari technical support, kemudian solusi tersebut akan disertai dengan nilai keyakinan dari technical support terhadap solusi yang diberikan tersebut. Selain itu, alasan dan pertimbangan lain penggunaan dan kombinasi metode forward chaining dan certainty factor karena pada penelitian [16] dan [17] telah menyatakan bahwa kedua metode ini memiliki nilai derajat keyakinan tertinggi dibandingkan metode lain ketika diterapkan dan dikombinasikan.

\section{B. Forward Chaining}

Proses forward chaining disajikan pada Gambar 1 [18].

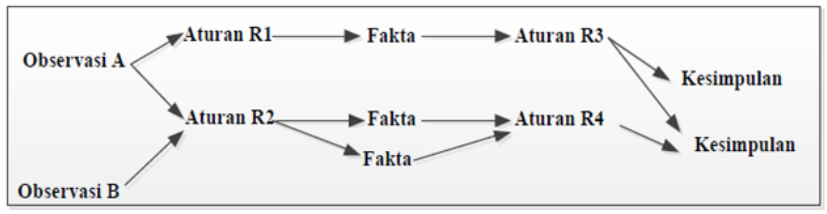

Gambar 1: Proses Forward Chaining

\section{Certainty Factor}

Berikut merupakan rumus dari metode Certainty Factor untuk mengansumsikan kepastian dan keyakinan seorang pakar terhadap suatu fakta, seperti dalam persamaan (1) [19].

$$
\begin{aligned}
& C F[H, E]=C F[H] * C F[E] \\
& C F \text { combine } C F[H, E] 1,2=C F[H, E] 1+C F[H, E] 2 * \\
& (1 C F[H, E] 1) C F \text { combine } C F[H, E] \text { old } 3= \\
& C F[H, E] \text { old }+C F[H, E] 3 *(1 C F[H, E] \text { old })
\end{aligned}
$$

Dimana :

- $\mathrm{CF}=$ Certainty Factor (Faktor Kepastian).

- $\mathrm{H}=$ Hipotesa.

- $\mathrm{E}=$ Evidence (Peristiwa atau Fakta).

Berikut merupakan standar rentang nilai (range) untuk beberapa pilihan jawaban dalam menentukan faktor kepastian (CF) sesuai dengan aturan yang terdapat pada metode certainty factor [18].

- Tidak Yakin = CFnya adalah 0

- Kurang Yakin = CFnya adalah 0,1 -0,4

- Cukup Yakin = CFnya adalah 0,5-0,7

- Yakin = CFnya adalah 0,8-0,9

- Sangat Yakin = CFnya adalah 1

\section{METODE PENELITIAN}

Sistem IT-helpdesk untuk maintenance dan tutorial aplikasi simplebiz menggunakan metode forward chaining dan p-ISSN:1693 - 2951; e-ISSN: 2503-2372 
certainty factor dirancang dan dibangun oleh penulis dengan menggunakan basis pengetahuan (knowledge base) dari technical support pada divisi IT-helpdesk di PT. Bamboomedia Cipta Persada. Berikut merupakan analisis sistem berbasis pengetahuan dari Rancang bangun sistem IThelpdesk untuk maintenance dan tutorial aplikasi simplebiz menggunakan metode forward chaining dan certainty factor.

\section{A. Basis Pengetahuan (Knowledge Base)}

Pengetahuan yang diperoleh merupakan hasil dari observasi sistem dan proses kerja yang terjadi pada lokasi penelitian dan hasil dari wawancara dengan kedua technical support dari divisi helpdesk di PT. Bamboomedia Cipta Persada, yaitu Bpk. I Putu Gede Sugiantara dan Bpk. Putu Eka Kresnanta Wijaya Adi Purnama. Berikut merupakan hasil wawancara dengan kedua technical support dari divisi helpdesk di PT. Bamboomedia Cipta Persada, yaitu Bpk. I Putu Gede Sugiantara dan Bpk. Putu Eka Kresnanta Wijaya Adi Purnama yang disajikan pada Tabel 1.

TABEL I

HASIL WAWANCARA

\begin{tabular}{|c|c|c|}
\hline PN & : & $\begin{array}{l}\text { Selamat siang, Bpk. I Putu Gede Sugiantara dan } \\
\text { Bpk. Putu Eka Kresnanta Wijaya Adi Purnama, } \\
\text { terimakasih sudah meluangkan waktu ditengah } \\
\text { kesibukan bapak sekalian untuk dapat } \\
\text { diwawancarai. }\end{array}$ \\
\hline $\begin{array}{l}\text { TS } 1 \text {, } \\
\text { TS } 2\end{array}$ & : & Selamat siang, baik silahkan. \\
\hline $\mathrm{PN}$ & : & $\begin{array}{l}\text { Baik saya akan mulai dengan pertanyaan pertama, } \\
\text { media komunikasi apa saja yang selama ini bapak } \\
\text { gunakan sebagai technical support dari PT. } \\
\text { Bamboomedia Cipta Persada dalam menangani } \\
\text { kendala dari pengguna aplikasi simplebiz? }\end{array}$ \\
\hline TS 1 & : & $\begin{array}{l}\text { Untuk berkomunikasi dengan pengguna aplikasi } \\
\text { simplebiz, kami selama ini menggunakan media } \\
\text { telepon, SMS, dan menggunakan beberapa } \\
\text { aplikasi chat seperti WhatsApp, Line, dan } \\
\text { Telegram. }\end{array}$ \\
\hline $\mathrm{PN}$ & : & $\begin{array}{l}\text { Apakah bapak menggunakan aplikasi khusus } \\
\text { dalam meng-handle kendala yang dialami oleh } \\
\text { pengguna aplikasi simplebiz? }\end{array}$ \\
\hline TS 2 & : & $\begin{array}{l}\text { Ya, kami menggunakan aplikasi remote desktop } \\
\text { connections Team Viewer dalam menangani } \\
\text { segala kendala yang dialami oleh para pengguna } \\
\text { aplikasi simplebiz. }\end{array}$ \\
\hline $\mathrm{PN}$ & : & $\begin{array}{l}\text { Sampai saat ini berapakah jumlah pengguna dari } \\
\text { aplikasi simplebiz di seluruh Indonesia? }\end{array}$ \\
\hline TS 1 & & $\begin{array}{l}\text { Jumlah pengguna dari aplikasi simplebiz yang } \\
\text { terdaftar di seluruh Indonesia sampai saat ini } \\
\text { mencapai } 10.508 \text { orang dan bahkan jumlah } \\
\text { tersebut dapat bertambah setiap harinya } \\
\text { tergantung dari jumlah penjualan aplikasi } \\
\text { tersebut. }\end{array}$ \\
\hline $\mathrm{PN}$ & : & $\begin{array}{l}\text { Dalam seharinya kira-kira berapa jumlah } \\
\text { pengguna aplikasi simplebiz yang masing-masing } \\
\text { bapak handle atau tangani? }\end{array}$ \\
\hline TS 2 & : & $\begin{array}{l}\text { Dilihat dari jumlah pengguna aplikasi simplebiz di } \\
\text { seluruh Indonesia tersebut, masing-masing dari } \\
\text { kami dalam seharinya dapat meng-handle sekitar } \\
60 \text { pengaduan kendala, baik secara bertatap muka, } \\
\text { melalui telepon, SMS, maupun melalui aplikasi } \\
\text { chat dan waktu yang dibutuhkan untuk dapat }\end{array}$ \\
\hline
\end{tabular}

\begin{tabular}{|c|c|c|}
\hline & & $\begin{array}{l}\text { menyelesaikan sebuah kendala tersebut adalah } \\
\text { sekitar } 20 \text { menit. }\end{array}$ \\
\hline PN & : & $\begin{array}{l}\text { Dengan banyaknya pengguna aplikasi simplebiz } \\
\text { di seluruh Indonesia dan juga dilihat dengan } \\
\text { semakin banyaknya pengaduan kendala dalam } \\
\text { seharinya, apakah bapak memiliki kesulitan } \\
\text { dalam menangani seluruh pengaduan kendala } \\
\text { tersebut? }\end{array}$ \\
\hline TS 2 & : & $\begin{array}{l}\text { Tentu saja, seperti yang kami beritahukan } \\
\text { sebelumnya, masing-masing dari kami dalam } \\
\text { seharinya dapat meng-handle sekitar } 60 \\
\text { pengaduan kendala dan } 4 \text { sampai dengan } 8 \\
\text { pengadukan kendala tersebut kami kerjakan } \\
\text { sekaligus dalam waktu yang bersamaan, hal ini } \\
\text { dikarenakan ketika kami sudah meng-handle satu } \\
\text { orang pengguna, pengguna lainnya juga } \\
\text { melakukan pengaduan kendala, dan kebetulan } \\
\text { juga jumlah technical support disini terbatas } \\
\text { sehingga mau tidak mau kami harus menangani } \\
\text { pengguna tersebut juga, hal ini terus berulang } \\
\text { sehingga jumlah pengaduan semakin banyak dan } \\
\text { menumpuk, hal inilah membuat kami kesulitan } \\
\text { dalam menangani kendala para pengguna aplikasi } \\
\text { simplebiz. }\end{array}$ \\
\hline PN & : & $\begin{array}{l}\text { Menurut bapak, apakah yang menyebabkan } \\
\text { semakin banyaknya pengaduan kendala yang } \\
\text { diadukan oleh para pengguna aplikasi simplebiz? }\end{array}$ \\
\hline TS 1 & : & $\begin{array}{l}\text { Menurut kami, ini disebabkan karena masih } \\
\text { banyaknya pengguna aplikasi simplebiz yang } \\
\text { masih sangat awam akan penggunaan sebuah } \\
\text { aplikasi bisnis, sehingga mereka sering } \\
\text { mengadukan hal-hal yang sifatnya sepele. Hal ini } \\
\text { membuat kami membutuhkan waktu yang cukup } \\
\text { lama untuk meng-handle pengguna seperti ini, } \\
\text { sehingga pengguna lain yang belum mendapat } \\
\text { giliran untuk ditangani akan menunggu lama dan } \\
\text { pengaduan kendala yang lain akan semakin } \\
\text { menumpuk. }\end{array}$ \\
\hline PN & : & $\begin{array}{l}\text { Ketika menangani kendala yang dialami oleh } \\
\text { pengguna aplikasi simplebiz tersebut, apakah } \\
\text { bapak membuat dan menggunakan sebuah data } \\
\text { yang berisi daftar kendala berserta solusi dari } \\
\text { kendala tersebut atau bapak menangani dan } \\
\text { menyelesaikan kendala tersebut hanya melalui } \\
\text { ilmu dan pengalaman yang selama ini kalian } \\
\text { miliki? }\end{array}$ \\
\hline TS 1 & : & $\begin{array}{l}\text { Pada awalnya kami tidak memiliki data seperti itu } \\
\text { dan kami hanya menangani dan menyelesaikan } \\
\text { kendala dari pengguna aplikasi simplebiz melalui } \\
\text { ilmu dan pengalaman yang kami miliki, namun } \\
\text { seiring berjalannya waktu dikarenakan jenis-jenis } \\
\text { kendala yang dialami oleh pengguna aplikasi } \\
\text { simplebiz mulai beragam dan jumlah pengguna } \\
\text { aplikasi simplebiz semakin banyak, jadi kami } \\
\text { menuangkan ilmu dan pengalaman kami dalam } \\
\text { menangani dan menyelesaikan kendala dari } \\
\text { pengguna aplikasi simplebiz ke dalam file } \\
\text { microsoft excel dan microsoft word yang berisi } \\
\text { daftar kendala berserta solusi dari kendala } \\
\text { tersebut, sehingga kami lebih mudah untuk } \\
\text { mengingat jenis kendala dan solusi dari kendala } \\
\text { tersebut. }\end{array}$ \\
\hline PN & & $\begin{array}{l}\text { Baik, jika berkenan apakah boleh saya } \\
\text { memperoleh file microsoft excel dan microsoft } \\
\text { word yang berisi daftar kendala berserta solusi } \\
\text { dari kendala tersebut sebagai bahan referensi }\end{array}$ \\
\hline
\end{tabular}




\begin{tabular}{|l|l|l|}
\hline & & $\begin{array}{l}\text { dalam penelitian saya yang berjudul Rancang } \\
\text { Bangun Sistem IT-Helpdesk Untuk Maintenance } \\
\text { dan Tutorial Aplikasi Simplebiz Menggunakan } \\
\text { Metode Forward Chaining dan Certainty Factor? }\end{array}$ \\
\hline $\begin{array}{l}\text { TS 1, } \\
\text { TS 2 }\end{array}$ & $:$ & Baik, silahkan dipergunakan sebaik mungkin. \\
\hline PN & $: \begin{array}{l}\text { Baik, terimakasih atas waktu dan informasinya. } \\
\text { Penelitian ini saya harapkan dapat membantu } \\
\text { mengatasi segala kesulitan yang bapak sekalian } \\
\text { alami dalam menangani kendala para pengguna } \\
\text { aplikasi simplebiz. }\end{array}$ \\
\hline TS 1, & $: \begin{array}{l}\text { Baik, semoga sistem tersebut dapat membantu } \\
\text { kami dalam menangani kendala para pengguna } \\
\text { aplikasi simplebiz. Terimakasih }\end{array}$ \\
\hline
\end{tabular}

Keterangan :

- PN : Peneliti.

- TS 1 : Bpk. I Putu Gede Sugiantara.

- TS 2 : Bpk. Putu Eka Kresnanta Wijaya Adi Purnama.

Selain melalui wawancara, pengetahuan juga diperoleh melalui kutipan dari buku, internet, dan jurnal, dimana semua pengetahuan-pengetahuan tersebut selanjutnya dikonversi menjadi sebuah tabel yang digunakan untuk mempermudah proses pencarian solusi sebagai pola pencocokan informasi yang dimasukkan oleh pemakai dan basis pengetahuan (knowledge base). Beberapa premis yang terdapat pada basis pengetahuan dari rancang bangun sistem IT-helpdesk untuk maintenance dan tutorial aplikasi simplebiz menggunakan metode forward chaining dan certainty factor disajikan pada Tabel 2.

TABEL II

BASIS PENGETAHUAN DARI TECHNICAL SUPPORT

\begin{tabular}{|l|l|}
\hline Kode & Premis \\
\hline P2 & Menggunakan Windows 7 \\
\hline P6 & Menggunakan Microsoft Office 2007 \\
\hline P10 & Menggunakan aplikasi Akuntansi 3.0 \\
\hline P11 & Menggunakan aplikasi Akademik Sekolah 3.0 \\
\hline P12 & Menggunakan aplikasi CustomerCare 2.0 \\
\hline P13 & Menggunakan aplikasi Hospital Express \\
\hline P14 & Menggunakan aplikasi Just POS \\
\hline P34 & $\begin{array}{l}\text { Mendala dalam proses instalasi dan aktivasi aplikasi } \\
\text { melakukan instalasi aplikasi }\end{array}$ \\
\hline P37 & $\begin{array}{l}\text { Muncul pesan "Error 20 : Sistem Trial pada program } \\
\text { Error." ketika pertama kali melakukan instalasi } \\
\text { aplikasi }\end{array}$ \\
\hline P38 & $\begin{array}{l}\text { Muncul pesan "Error No : 10, File Pendukung } \\
\text { Program tidak lengkap atau rusak, silahkan install } \\
\text { melakukan instalasi aplikasi }\end{array}$ \\
\hline P39 program secara benar." ketika pertama kali \\
\hline P41 & $\begin{array}{l}\text { Muncul pesan "Error No : 11, File Pendukung } \\
\text { ulang program secara benar." ketika pertama kali } \\
\text { melakukan instalasi aplikasi }\end{array}$ \\
\hline P40 \\
Muncul pesan "Aktivasi Error jalankan program \\
\hline
\end{tabular}

\begin{tabular}{|l|l|}
\hline & $\begin{array}{l}\text { secara benar" ketika pertama kali melakukan instalasi } \\
\text { aplikasi }\end{array}$ \\
\hline P55 & $\begin{array}{l}\text { Muncul pesan "Aplikasi tidak dapat dijalankan" pada } \\
\text { aplikasi }\end{array}$ \\
\hline
\end{tabular}

Tabel 2 merupakan contoh dari beberapa kendala (premis) yang dialami oleh pengguna aplikasi simplebiz, dimana data ini diperoleh melalui hasil wawancara dengan kedua technical support dari PT. Bamboomedia Cipta Persada, kutipan dari buku, internet, dan jurnal terkait. Beberapa data konklusi dari premis-premis pada tabel basis pengetahuan (knowledge base) tersebut disajikan pada Tabel 3.

TABEL III

KonKLUSi DARI PREMIS PADA BASIS PENGETAHUAN DARI TECHNICAL SUPPORT

\begin{tabular}{|c|c|}
\hline Kode & Konklusi \\
\hline K123 & $\begin{array}{l}\text { Tampilkan tutorial setting awal Windows 7, setting } \\
\text { awal Microsoft Office Access } 2007 \text { dan } \\
\text { instalasi/aktivasi aplikasi Akuntansi 3.0 }\end{array}$ \\
\hline K124 & $\begin{array}{l}\text { Tampilkan tutorial setting awal Windows 7, setting } \\
\text { awal Microsoft } \quad \text { Office } \quad \text { Access } 2007 \text { dan } \\
\text { instalasi/aktivasi aplikasi Akademik Sekolah 3.0 }\end{array}$ \\
\hline K125 & $\begin{array}{l}\text { Tampilkan tutorial setting awal Windows } 7 \text {, setting } \\
\text { awal Microsoft Office Access } 2007 \text { dan } \\
\text { instalasi/aktivasi aplikasi Customer Care } 2.0\end{array}$ \\
\hline K126 & $\begin{array}{l}\text { Tampilkan tutorial setting awal Windows 7, setting } \\
\text { awal Microsoft Office Access } 2007 \text { dan } \\
\text { instalasi/aktivasi aplikasi Hospital Express }\end{array}$ \\
\hline K127 & $\begin{array}{l}\text { Tampilkan tutorial setting awal Windows 7, setting } \\
\text { awal Microsoft Office Access } 2007 \text { dan } \\
\text { instalasi/aktivasi aplikasi Just POS }\end{array}$ \\
\hline
\end{tabular}

Tabel 3 merupakan contoh dari beberapa solusi (konklusi) sesuai dengan kendala (premis) yang terdapat pada Tabel 2, dimana data ini juga diperoleh melalui hasil wawancara dengan kedua technical support dari PT. Bamboomedia Cipta Persada, kutipan dari buku, internet, dan jurnal terkait.

\section{B. Kaidah Produksi (Rule Base) dan Nilai CF (Keyakinan} Pakar) untuk Masing-Masing Premis Terhadap Konklusi

Setelah berhasil merancang tabel basis pengetahuan (knowledge base), selanjutnya adalah merancang sebuah kaidah produksi (rule base) dan menentukan nilai CF (keyakinan technical support) untuk masing-masing premis terhadap konklusi, namun sebelum itu diperlukan sebuah rentang nilai (range) untuk dapat menentukan nilai CF dari technical support dan pengguna aplikasi simplebiz.

Dalam menentukan rentang nilai (range) tersebut akan digunakan rumus statistika yaitu distribusi frekuensi yang disesuaikan dengan standar rentang nilai (range) yang terdapat pada metode certainty factor. Distribusi frekuensi sangat cocok dan akurat digunakan dalam menentukan sebuah interval kelas dari sebuah rangkaian data [20]. Persamaan dari distribusi frekuensi adalah, seperti dalam persamaan (2) [20].

I Gusti Ngurah Wira Partha: Rancang Bangun Sistem IT-Helpdesk... 


$$
\begin{aligned}
& R=X \max -X \min \\
& K=1+3,33 \log N \\
& I=R / K
\end{aligned}
$$

Dimana :

- $\mathrm{R}=$ Rentang (Range) .

- $\mathrm{Xmax}=$ Nilai Maksimum.

- $\mathrm{Xmin}=$ Nilai Minimum.

- $\mathrm{K}=$ Kelas

- $\mathrm{N}=$ Banyak Data

- $\mathrm{I}=$ Interval Kelas.

Diketahui masing-masing nilai dari standar rentang nilai (range) yang terdapat pada metode certainty factor yaitu $0 ; 0,1$; 0,$2 ; 0,3 ; 0,4 ; 0,5 ; 0,6 ; 0,7 ; 0,8 ; 0,9 ; 1$, maka untuk memperoleh interval kelas (I) adalah, seperti dalam persamaan (3).

$$
\begin{aligned}
& R=1-0 \\
& R=1 \\
& K=1+3,33 \log 11 \\
& K=4,468 \\
& K=4 \\
& I=1 / 4 \\
& I=0,25
\end{aligned}
$$

(3)

Berdasarkan hasil perhitungan tersebut, maka diperoleh interval kelas (I) yaitu 0,25 sehingga akan menghasilkan rentang nilai (range) untuk menentukan nilai CF dari technical support sebagai berikut.

- Tidak Yakin = CFnya adalah $0-0,24$

- Cukup Yakin = CFnya adalah 0,25 - 0,49

- Yakin = CFnya adalah 0,50-0,74

- Sangat Yakin = CFnya adalah 0,75-1

Rentang nilai (range) tersebut akan digunakan oleh technical support dalam menentukan nilai CF (keyakinan technical support) dari masing-masing premis terhadap konklusi, kemudian untuk memperoleh nilai CF dari pengguna aplikasi simplebiz akan digunakan batas atas kelas dari masing-masing rentang nilai (range) yang telah diperoleh sebelumnya, selain itu untuk mengoptimalisasi nilai CF konklusi, maka pilihan “Tidak Yakin” tidak akan ditampilkan ketika pengguna aplikasi simplebiz memilih tingkat keyakinan tersebut, sehingga nilai CF dari pengguna aplikasi simplebiz adalah sebagai berikut.

- Cukup Yakin = CFnya adalah 0,49

- Yakin = CFnya adalah 0,74

- Sangat Yakin = CFnya adalah 1

Tahap selanjutnya adalah merancang sebuah kaidah produksi (rule base) dan menentukan nilai CF (keyakinan technical support) untuk masing-masing premis terhadap konklusi. Premis (ciri-ciri kendala) dan konklusi (solusi

\begin{tabular}{|c|c|c|c|c|}
\hline $\begin{array}{l}\text { Konklusi } \\
\text { (Solusi } \\
\text { Perbaikan) } \\
\text { (Nilai CF) }\end{array}$ & $\begin{array}{l}\text { Aplikasi } \\
\text { (Nilai CF) }\end{array}$ & $\begin{array}{l}\text { Sistem } \\
\text { Operasi } \\
\text { (Nilai CF) }\end{array}$ & $\begin{array}{l}\text { Ms. Office } \\
\text { (Nilai CF) }\end{array}$ & $\begin{array}{l}\text { Kendala } \\
\text { (Nilai CF) }\end{array}$ \\
\hline K123 & P10 $(0,2)$ & P2 $(0,3)$ & P6 $(0,4)$ & $\begin{array}{l}\text { P34 (0,9), } \\
\text { P37 (1), } \\
\text { P38 (1), } \\
\text { P39 (1), } \\
\text { P40 (1), } \\
\text { P41 (1), } \\
\text { P53 (0,9), } \\
\text { P55 }(0,9)\end{array}$ \\
\hline K124 & P11 $(0,2)$ & P2 $(0,3)$ & P6 $(0,4)$ & $\begin{array}{l}\text { P34 (0,9), } \\
\text { P37 (1), } \\
\text { P38 (1), } \\
\text { P39 (1), } \\
\text { P40 (1), } \\
\text { P41 (1), } \\
\text { P53 }(0,9), \\
\text { P55 }(0,9)\end{array}$ \\
\hline K125 & P12 $(0,2)$ & P2 $(0,3)$ & P6 $(0,4)$ & $\begin{array}{l}\text { P34 (0,9), } \\
\text { P37 (1), } \\
\text { P38 (1), } \\
\text { P39 (1), } \\
\text { P40 (1), } \\
\text { P41 }(1), \\
\text { P53 }(0,9), \\
\text { P55 }(0,9)\end{array}$ \\
\hline K126 & P13 $(0,2)$ & P2 $(0,3)$ & P6 $(0,4)$ & $\begin{array}{l}\text { P34 (0,9), } \\
\text { P37 (1), } \\
\text { P38 (1), } \\
\text { P39 (1), } \\
\text { P40 (1), } \\
\text { P41 (1), } \\
\text { P53 }(0,9), \\
\text { P55 }(0,9)\end{array}$ \\
\hline K127 & $\mathrm{P} 14(0,2)$ & P2 $(0,3)$ & P6 $(0,4)$ & $\begin{array}{l}\text { P34 (0,9), } \\
\text { P37 (1), } \\
\text { P38 (1), } \\
\text { P39 (1), } \\
\text { P40 (1), } \\
\text { P41 (1), } \\
\text { P53 }(0,9), \\
\text { P55 }(0,9)\end{array}$ \\
\hline
\end{tabular}
perbaikan) dapat dihubungkan sehingga akan membentuk sebuah kaidah produksi (rule base), kemudian menentukan nilai CF (keyakinan technical support) dari masing-masing premis (ciri-ciri kendala) terhadap konklusi (solusi perbaikan). Beberapa data hubungan dari premis (ciri-ciri kendala), konklusi (solusi perbaikan), dan nilai CF (keyakinan technical support) tersebut disajikan pada Tabel 4.

TABEL IV

HuBUNGAN PREMIS, KONKLUSI, DAN NILAI CF

Tabel 4 merupakan contoh dari beberapa hubungan dari kendala (premis) pada Tabel 2 dengan solusi (konklusi) pada Tabel 3 yang disertai dengan nilai CF (keyakinan technical support) terhadap kendala (premis) dan solusi (konklusi) tersebut.

\section{Analisis Metode Forward Chaining dan Certainty Factor}

Rancang bangun sistem IT-helpdesk untuk maintenance dan tutorial aplikasi simplebiz menggunakan metode forward chaining dan certainty factor dapat mengidentifikasi output 
Majalah Ilmiah Teknologi Elektro, Vol. 20, No.2, Juli - Desember 2021

DOI: https://doi.org/10.24843/MITE.2021.v20i02.P16

apabila sudah menerima input yang diperlukan. Setiap premis (kendala) yang dipilih oleh pengguna menghasilkan output berupa kesimpulan. Kesimpulan tersebut berupa konklusi (solusi) dari premis (kendala) pengguna aplikasi simplebiz, sehingga pengguna aplikasi simplebiz dapat menggunakan atau melakukan maintenance aplikasi simplebiz yang dimilikinya secara mandiri tanpa perlu bertatap muka secara langsung dengan technical support. Untuk mendapatkan kesimpulan, maka hal yang harus dilakukan pertama adalah mengetahui dan menentukan premis, selanjutnya dilakukan proses penalaran runut maju (IF-THEN) berdasarkan premis tersebut menggunakan metode forward chaining hingga konklusi dari premis-premis tersebut dapat diketahui dan diperoleh.

Selanjutnya berdasarkan metode certainty factor, maka dilakukan penentuan nilai CF (kepercayaan pakar) dari premis-premis yang telah diketahui terhadap konklusi yang didapat melalui metode forward chaining, kemudian dari nilai CF (kepercayaan pakar) tersebut dilakukan perhitungan dengan nilai kepercayaan berdasarkan tingkat kepercayaan kendala yang dimiliki oleh pengguna aplikasi simplebiz (nilai CF Premis) untuk mendapatkan kesimpulan yaitu nilai CF Konklusi. Nilai CF Konklusi inilah yang akan dijadikan parameter untuk solusi dari kendala pengguna aplikasi simplebiz. Berikut adalah contoh kasus untuk memperoleh Nilai CF Konklusi :

- Langkah pertama, pengguna aplikasi simplebiz memilih premis-premis sesuai dengan kendala yang dialaminya pada aplikasi simplebiz, dimana premis-premis ini diperoleh melalui basis pengetahuan (knowledge base) yang telah diketahui dan ditentukan sebelumnya, selain itu premis-premis yang dipilih oleh pengguna aplikasi simplebiz tersebut telah dirunut maju dan diatur berdasarkan metode forward chaining sesuai dengan tabel basis pengetahuan (knowledge base) dari technical support, tabel konklusi dari premis pada basis pengetahuan dari technical support, dan tabel hubungan premis, konklusi, dan nilai CF. Berikut adalah premispremis yang dipilih oleh pengguna aplikasi simplebiz.

P10 = Menggunakan aplikasi Akuntansi 3.0

P2 = Menggunakan Windows 7

P6 = Menggunakan Microsoft Office 2007

P37 = Muncul pesan "Error 500" ketika pertama kali melakukan instalasi aplikasi

Selama memilih premis-premis tersebut, pengguna aplikasi simplebiz akan diminta untuk memilih tingkat keyakinan terhadap premis-premis tersebut sesuai dengan pilihan tingkat keyakinan yang telah ditentukan dan diketahui sebelumnya. Pengguna aplikasi simplebiz tidak perlu menginputkan nilai CF ketika memilih tingkat keyakinan terhadap premis-premis tersebut karena nilai CF sudah ditentukan sesuai dengan rentang nilai (range) dari pengguna aplikasi simplebiz yang telah diketahui sebelumnya. Berikut adalah tingkat keyakinan yang dipilih oleh pengguna aplikasi simplebiz terhadap premis-premis yang dipilih
321

sebelumnya, sehingga akan menghasilkan nilai CF Premis dari masing-masing premis yang dipilih tersebut.

P10 = Menggunakan aplikasi Akuntansi 3.0 (Yakin = $0,74)$

P2 = Menggunakan Windows 7 (Cukup Yakin = 0,49)

P6 = Menggunakan Microsoft Office 2007 (Cukup Yakin $=0,49$ )

P37 = Muncul pesan "Error 500" ketika pertama kali melakukan instalasi aplikasi (Sangat Yakin =1)

- Langkah kedua berdasarkan metode forward chaining dan kaidah produksi (rule base) yang telah diketahui dan ditentukan sebelumnya, maka premis-premis yang dipilih oleh pengguna aplikasi simplebiz akan menghasilkan sebuah diagram pohon keputusan (decision tree diagram) yang disajikan pada Gambar 2 dan rule sebagai berikut.

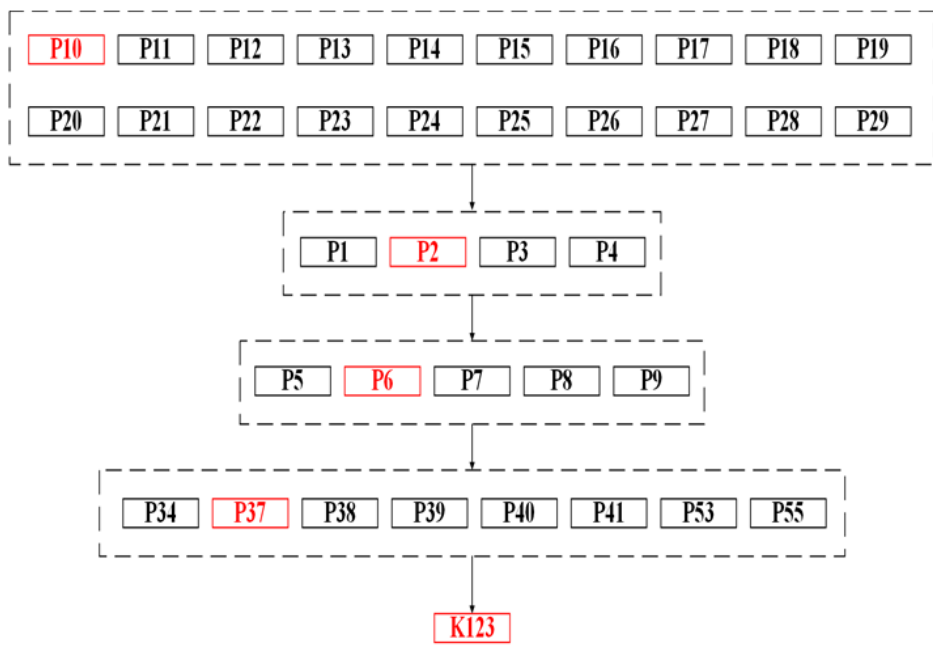

Gambar 2: Diagram Pohon Keputusan (Decision Tree Diagram)

Berdasarkan Gambar 1. Diagram Pohon Keputusan (Decision Tree Diagram) maka Rule yang dihasilkan adalah sebagai berikut.

IF P10

AND P2

AND P6

AND P37

THEN K123

Sesuai dengan proses penalaran runut maju (IF-THEN) dari premis-premis tersebut, maka akan menghasilkan sebuah konklusi, dimana konklusi ini diperoleh dari tabel konklusi dari premis pada basis pengetahuan dari technical support dan kaidah produksi (rule base) yang telah diketahui dan ditentukan sebelumnya. Konklusi dari premis-premis yang dipilih oleh pengguna aplikasi simplebiz adalah sebagai berikut. 
K123 = Tampilkan tutorial setting awal Windows 7, setting awal Microsoft Office Access 2007 dan instalasi/aktivasi aplikasi Akuntansi 3.0.

- Langkah ketiga berdasarkan metode certainty factor, basis pengetahuan (knowledge base), dan kaidah produksi (rule base) yang telah diketahui dan ditentukan sebelumnya, maka nilai CF (keyakinan technical support) dari masing-masing premis terhadap konklusi tersebut adalah sebagai berikut.

P10 = Menggunakan aplikasi Akuntansi 3.0 (Kurang Yakin $=0,2$ )

P2 = Menggunakan Windows 7 (Kurang Yakin = 0,3)

P6 = Menggunakan Microsoft Office 2007 (Kurang Yakin $=0,4$ )

P37 = Muncul pesan "Error 500" ketika pertama kali melakukan instalasi aplikasi $($ Yakin $=0,9)$

- Langkah selanjutnya sesuai dengan proses dari metode forward chaining dan metode certainty factor yang telah dilakukan diatas, maka akan dilakukan kalkulasi dan perhitungan terhadap nilai CF (keyakinan technical support) dan nilai CF Premis (keyakinan pengguna aplikasi simplebiz) yang akan menghasilkan nilai CF Konklusi (keyakinan solusi), seperti dalam persamaan (4).

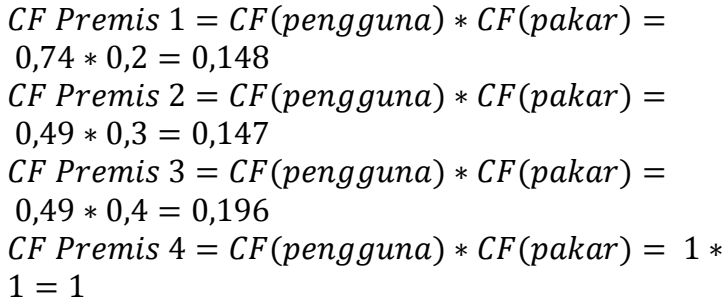

Dikarenakan terdapat lebih dari satu premis, maka untuk menentukan CF Konklusi selanjutnya digunakan persamaan sebagai berikut, seperti dalam persamaan (5).

CF Konklusi $1(C F$ Premis 1, CF Premis 2$)=C F$ Premis $1+$ CF Premis $2 *(1-$

CF Premis 1)CF Konklusi 1 (CF Premis $1, C F$ Premis 2$)=$ $0,148+0,147 *(1-0,148) C F$ Konklusi $1=$ 0,251 CF Konklusi $1=0,251$

CF Konklusi $2(C F$ Konklusi $1, C F$ Premis 3$)=$ CF Konklusi $1+C F$ Premis $3 *(1-$ CF Konklusi 1)CF Konklusi $2($ CF Konklusi $1, C F$ Premis 3$)=$ $0,251+0,196 *(1-0,251) C F$ Konklusi $2=$ 0,335 CF Konklusi $2=0,335$

CF Konklusi 3(CF Konklusi 2, CF Premis 4$)=$ CF Konklusi $2+C F$ Premis $4 *(1-$ CF Konklusi 2)CF Konklusi 3(CF Konklusi 2, CF Premis 4$)=$ $0,335+1 *(1-0,335) C F$ Konklusi $3=$ 0,888 CF Konklusi $3=0,888$

Berdasarkan hasil perhitungan nilai CF tersebut, maka CF Konklusi adalah 0,888. Kemudian untuk langkah terakhir adalah menghitung persentase keyakinan terhadap konklusi dari contoh kasus tersebut), seperti dalam persamaan (6).

$$
\begin{aligned}
& \text { Persentase Keyakinan }=C F \text { Konklusi } * 100 \% \\
& \text { Persentase Keyakinan }=0,888 * 100 / 100 \\
& \text { Persentase Keyakinan }=89 \%
\end{aligned}
$$

Berdasarkan hasil perhitungan dari contoh kasus tersebut, maka persentase keyakinan technical support terhadap solusi yang diberikan kepada pengguna aplikasi simplebiz adalah sebesar 89\%. Untuk menentukan keyakinan dari output yang dihasilkan oleh sistem terhadap kontribusi penyelesaian masalah dari contoh kasus tersebut dapat dilihat dari ketentuan berikut :

Jika Nilai Persentase Keyakinan $>=0 \%$ dan $<=35 \%$ : Tidak Tahu

Jika Nilai Persentase Keyakinan $>35 \%$ dan $<=55 \%$ : Mungkin

Jika Nilai Persentase Keyakinan $>55 \%$ dan $<=75 \%$ : Kemungkinan Besar

Jika Nilai Persentase Keyakinan $>75 \%$ dan $<=95 \%$ : Hampir Pasti

Jika Nilai Persentase Keyakinan $>95 \%$ dan $<=100 \%$ : Pasti

Berdasarkan ketentuan tersebut, maka tingkat keyakinan dari output yang dihasilkan oleh sistem terhadap kontribusi penyelesaian masalah dari contoh kasus tersebut adalah HAMPIR PASTI. Hal tersebut membuktikan bahwa penerapan metode forward chaining dan certainty factor pada sistem IT-helpdesk untuk maintenance dan tutorial aplikasi simplebiz ini sudah tepat dan HAMPIR PASTI dapat menyelesaikan kendala yang dialami oleh pengguna aplikasi simplebiz.

\section{Hasil Dan PEMbahasan}

\section{A. Tahap Implementasi}

Pada tahap implementasi, penulis merancang dan membangun sebuah sistem berbentuk responsive website yang dijalankan secara online, yaitu sistem IT-helpdesk untuk maintenance dan tutorial aplikasi simplebiz menggunakan metode forward chaining dan certainty factor. Sistem ini akan digunakan oleh pengguna aplikasi simplebiz yang sudah terdaftar pada PT. Bamboomedia Cipta Persada, dimana jumlah dari pengguna aplikasi simplebiz yang terdaftar di seluruh Indonesia sampai saat ini mencapai 10.508 orang. Berikut adalah implementasi halaman antarmuka (interface) dari sistem IT-helpdesk untuk maintenance dan tutorial aplikasi simplebiz menggunakan metode forward chaining dan certainty factor

- Implementasi Halaman Utama (Home) dari sistem IThelpdesk untuk maintenance dan tutorial aplikasi simplebiz menggunakan metode forward chaining dan certainty factor disajikan pada Gambar 3. 
Majalah Ilmiah Teknologi Elektro, Vol. 20, No.2, Juli - Desember 2021

DOI: https://doi.org/10.24843/MITE.2021.v20i02.P16 


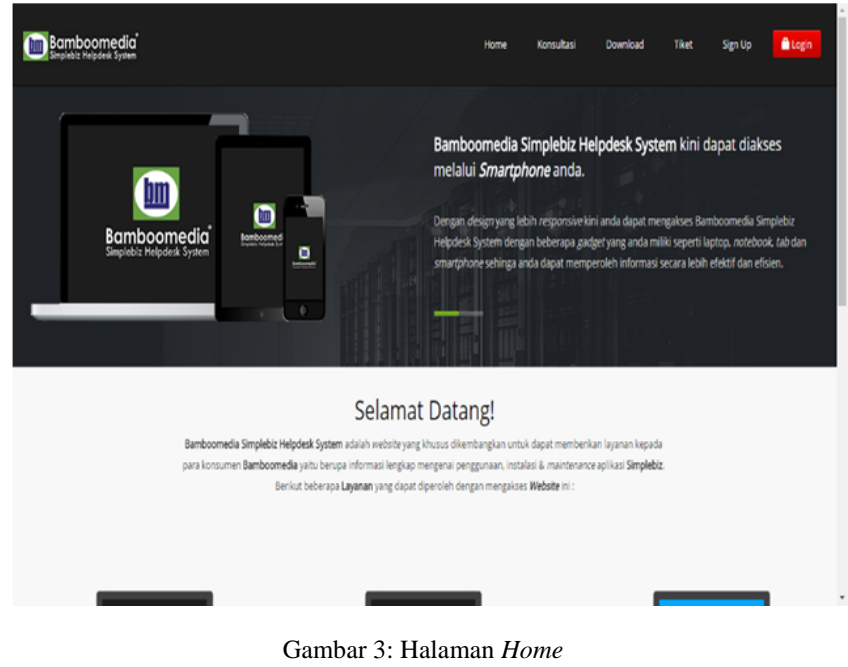

Pada halaman ini terdapat beberapa informasi mengenai ketentuan layanan dan fitur-fitur yang dapat digunakan pada sistem ini, selain itu terdapat juga beberapa informasi mengenai alamat dan kontak dari perusahaan PT. Bamboomedia Cipta Persada.

- Implementasi Halaman Konsultasi dari sistem IThelpdesk untuk maintenance dan tutorial aplikasi simplebiz menggunakan metode forward chaining dan certainty factor disajikan pada Gambar 4.

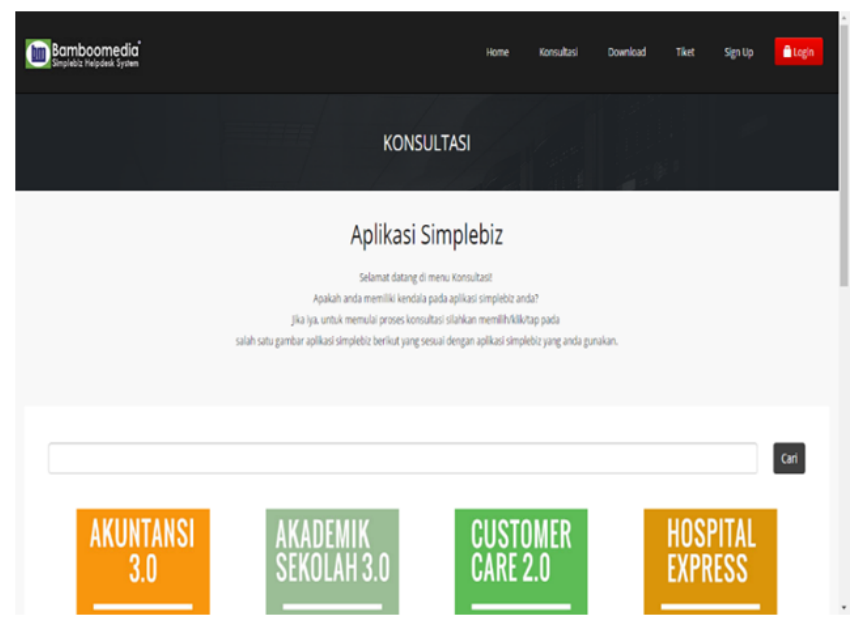

Gambar 4: Halaman Konsultasi Aplikasi

Pada halaman ini pengguna aplikasi simplebiz (user) dapat seolah-olah berkonsultasi dengan technical support secara langsung, dimana pada halaman ini akan muncul beberapa pertayaan yang bersifat umum hingga spesifik mengenai kendala yang dialami oleh pengguna aplikasi simplebiz. Pada halaman ini akan muncul sebuah pertanyaan yang dimana pengguna akan diminta untuk menjawab dan memilih aplikasi simplebiz yang digunakan tersebut. Sebagai uji coba, pada pertanyaan ini dijawab dan dipilih aplikasi 'Akuntansi 3.0', selanjutnya akan diarahkan ke halaman pemilihan tingkat keyakinan terhadap jawaban dari pertanyaan sebelumnya mengenai aplikasi simplebiz yang digunakan tersebut yang disajikan pada Gambar 5.

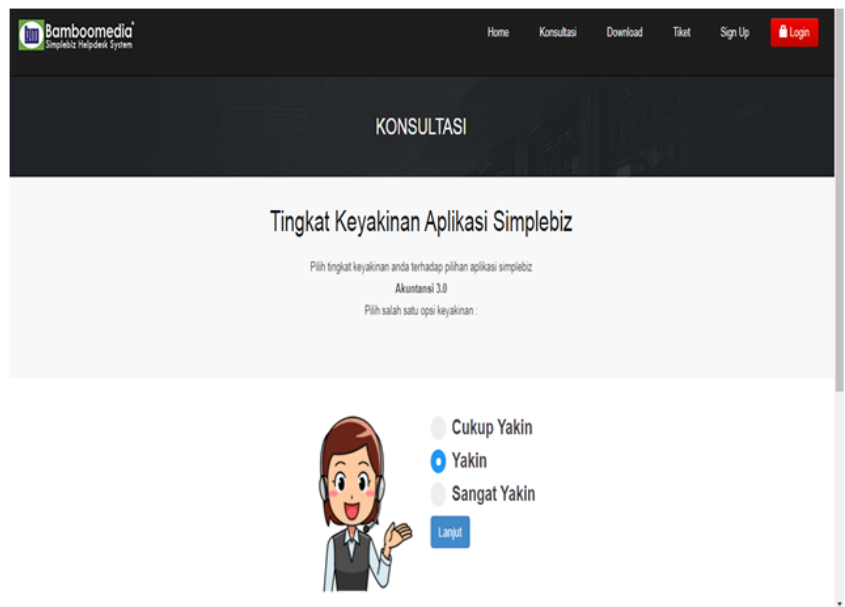

Gambar 5: Halaman Konsultasi Tingkat Keyakinan Aplikasi

Sebagai uji coba, pada pertanyaan ini dijawab dan dipilih 'Yakin' terhadap jawaban sebelumnya yaitu aplikasi 'Akuntansi 3.0'. Selanjutnya akan diarahkan ke halaman konsultasi sistem operasi yang disajikan pada Gambar 6.

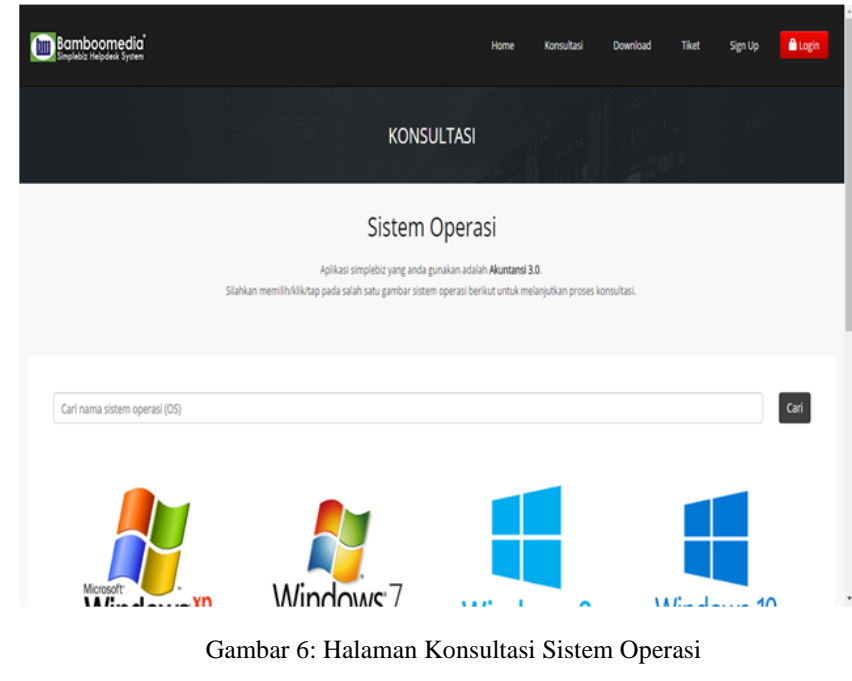

Pada halaman ini pengguna aplikasi simplebiz akan diminta untuk menjawab dan memilih sistem operasi yang digunakan pada komputer atau laptop yang terinstall aplikasi simplebiz. Sebagai uji coba, pada pertanyaan ini dijawab dan dipilih 'Windows 7', selanjutnya akan diarahkan ke halaman pemilihan

(10) Bamboomedid

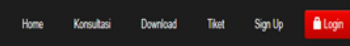

KONSULTAS

Tingkat Keyakinan Sistem Operasi

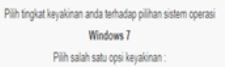


Majalah Ilmiah Teknologi Elektro, Vol. 20, No.2, Juli - Desember 2021

DOI: https://doi.org/10.24843/MITE.2021.v20i02.P16

tingkat keyakinan terhadap jawaban dari pertanyaan sebelumnya mengenai sistem operasi yang digunakan pada komputer atau laptop yang ter-install aplikasi simplebiz yang disajikan pada Gambar 7.

Gambar 7: Halaman Konsultasi Tingkat Keyakinan Sistem Operasi

Sebagai uji coba, pada pertanyaan ini dijawab dan dipilih 'Cukup Yakin' terhadap jawaban sebelumnya yaitu 'Windows 7'. Selanjutnya akan diarahkan ke halaman konsultasi ms. office yang disajikan pada Gambar 8.
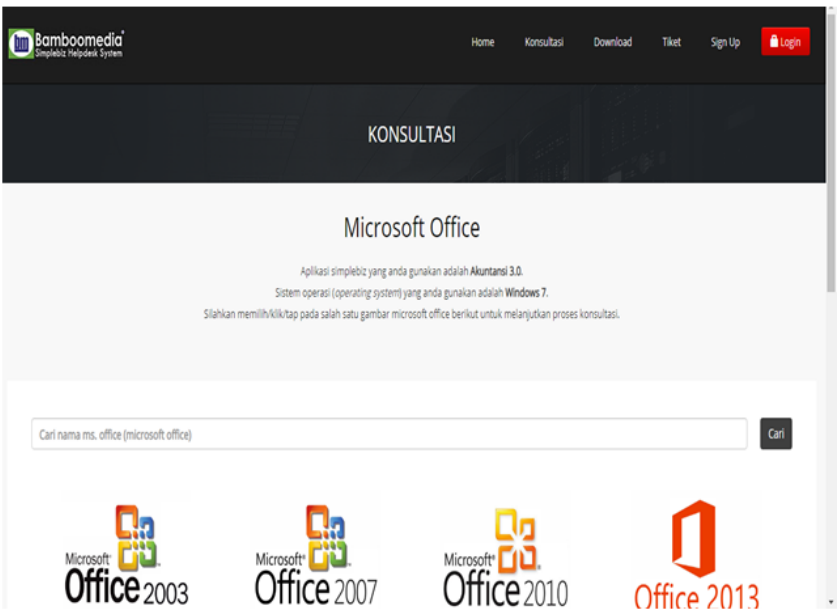

Gambar 8: Halaman Konsultasi Ms. Office

Pada halaman ini pengguna aplikasi simplebiz akan diminta untuk menjawab dan memilih microsoft office yang digunakan pada komputer atau laptop yang terinstall aplikasi simplebiz. Sebagai uji coba, pada pertanyaan ini dijawab dan dipilih 'Microsoft Office 2007', selanjutnya akan diarahkan ke halaman pemilihan tingkat keyakinan terhadap jawaban dari pertanyaan sebelumnya mengenai microsoft office yang digunakan pada komputer atau laptop yang ter-install aplikasi simplebiz yang disajikan pada Gambar 9.

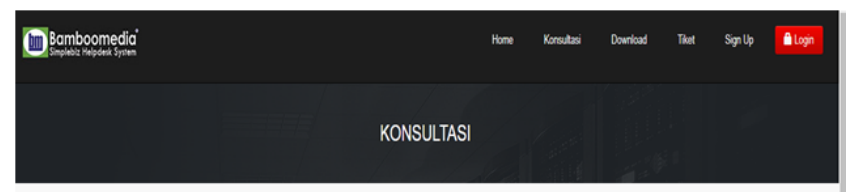

Tingkat Keyakinan Microsoft Office

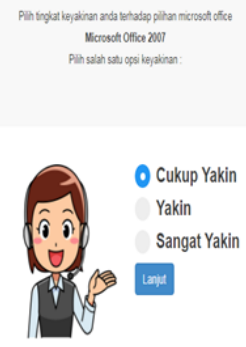

I Gusti Ngurah Wira Partha: Rancang Bangun Sistem IT-Helpdesk...
Gambar 9: Halaman Konsultasi Tingkat Keyakinan Ms. Office

Sebagai uji coba, pada pertanyaan ini dijawab dan dipilih 'Cukup Yakin' terhadap jawaban sebelumnya yaitu 'Microsoft Office 2007'. Selanjutnya akan diarahkan ke halaman konsultasi kendala yang disajikan pada Gambar 10.

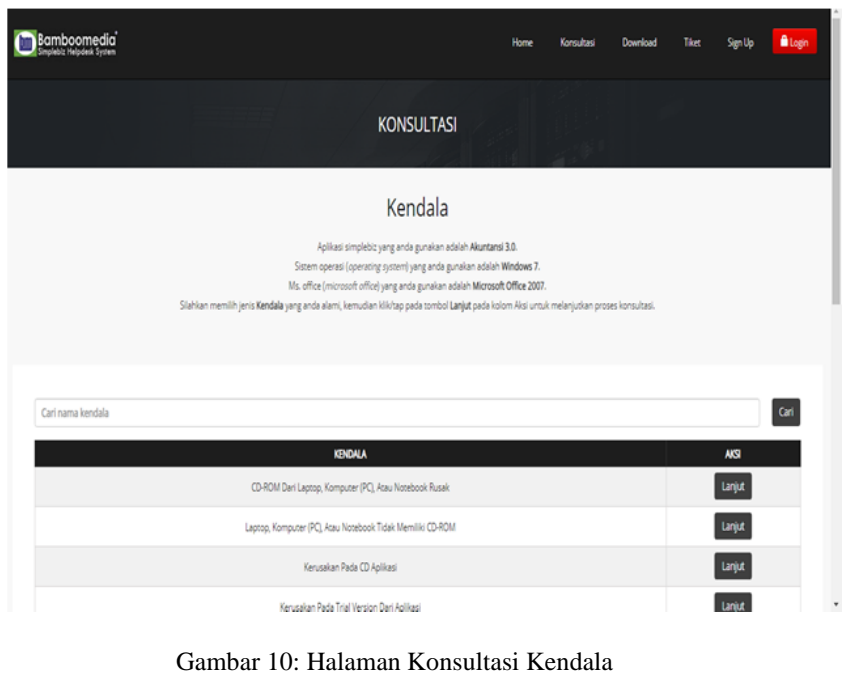

Pada halaman ini pengguna aplikasi simplebiz akan diminta untuk menjawab dan memilih kendala yang dialami pada aplikasi simplebiz yang digunakan. Pada halaman ini juga terdapat sebuah kolom pencarian (search), dimana pengguna aplikasi simplebiz dapat memasukkan atau menginputkan kata kunci (keyword) dari kendala yang dialami untuk dipilih. Sebagai uji coba, pada pertanyaan ini dijawab dan dipilih kendala 'Muncul pesan "Error 500" ketika pertama kali melakukan instalasi aplikasi', selanjutnya akan diarahkan ke halaman pemilihan tingkat keyakinan terhadap jawaban dari pertanyaan sebelumnya mengenai kendala yang dialami pada aplikasi simplebiz yang digunakan yang disajikan pada Gambar 11.

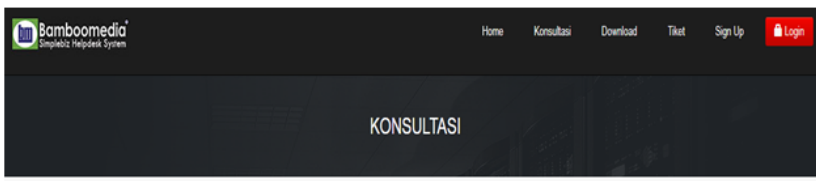

Tingkat Keyakinan Kendala

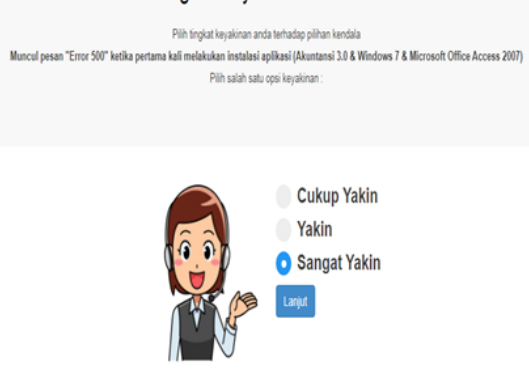

p-ISSN:1693 - 2951; e-ISSN: 2503-2372 
Gambar 11: Halaman Konsultasi Tingkat Keyakinan Kendala

Sebagai uji coba, pada pertanyaan ini dijawab dan dipilih 'Sangat Yakin' terhadap jawaban sebelumnya yaitu kendala 'Muncul pesan "Error 500" ketika pertama kali melakukan instalasi aplikasi’. Selanjutnya akan diarahkan ke halaman konsultasi solusi \& tingkat keyakinan technical support yang disajikan pada Gambar 12.

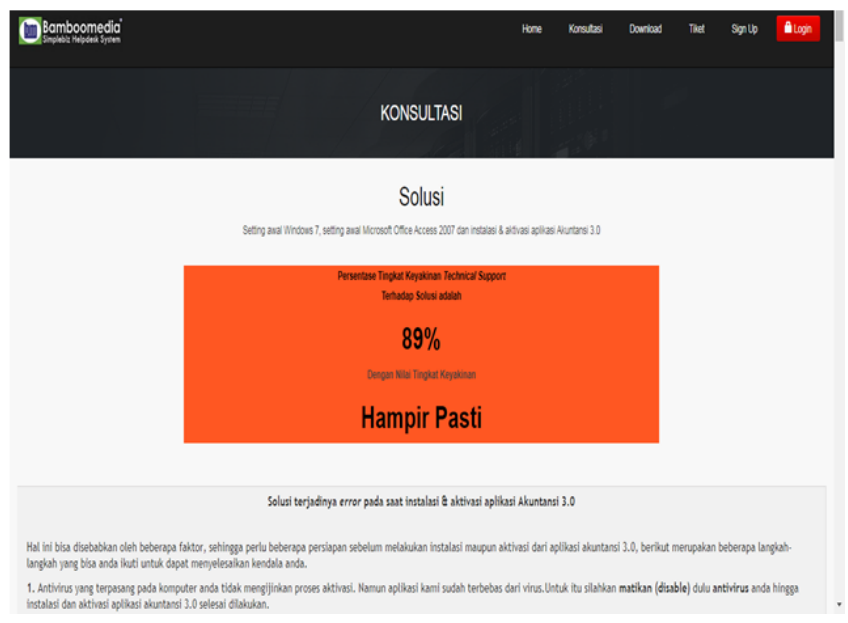

Gambar 12: Halaman Konsultasi Solusi \& Tingkat Keyakinan Technical Support

Pada halaman ini pengguna aplikasi simplebiz akan disajikan sebuah solusi berupa tutorial yang dapat digunakan untuk menyelesaikan kendala yang dialami oleh pengguna aplikasi simplebiz, selain itu pada halaman ini juga menampilkan persentase tingkat keyakinan dan nilai tingkat keyakinan technical support terhadap solusi yang diberikan tersebut.

Berdasarkan uji coba yang telah dilakukan, dimana jawaban-jawaban tersebut yaitu menggunakan aplikasi simplebiz 'Akuntansi 3.0' dengan tingkat keyakinan 'Yakin', menggunakan sistem operasi 'Windows 7' dengan tingkat keyakinan 'Cukup Yakin', menggunakan 'Microsoft Office 2007' dengan tingkat keyakinan 'Cukup Yakin', dan mengalami kendala 'Muncul pesan "Error 500" ketika pertama kali melakukan instalasi aplikasi' dengan tingkat keyakinan 'Sangat Yakin', maka solusi yang diberikan oleh sistem adalah menampilkan tutorial 'Setting awal Windows 7, setting awal Microsoft Office Access 2007 dan instalasi \& aktivasi aplikasi Akuntansi 3.0` dengan persentase tingkat keyakinan technical support terhadap solusi yang diberikan yaitu '89\%' dengan nilai tingkat keyakinan yaitu 'Hampir Pasti’.

Hasil ini diperoleh melalui proses analisis dan perhitungan terhadap jawaban-jawaban pengguna aplikasi simplebiz dari pertanyaan-pertanyaan yang diberikan oleh sistem dengan menggunakan kombinasi metode forward chaining dan certainty factor yang telah berhasil diterapkan dan diimplementasikan pada sistem yang dirancang dan dibangun.

\section{B. Analisa Hasil Pengujian}

Berdasarkan implementasi dan pengujian yang telah dilakukan, menunjukkan bahwa sistem IT-helpdesk untuk maintenance dan tutorial aplikasi simplebiz menggunakan metode forward chaining dan certainty factor dapat digunakan oleh para pengguna aplikasi simplebiz untuk berkonsultasi dan memperoleh solusi yang akurat dari kendala yang dialami layaknya berkonsultasi secara langsung dengan seorang technical support, sehingga para pengguna aplikasi simplebiz dapat mengatasi kendala yang dialaminya secara mandiri. Hal ini dapat dibuktikan melalui hasil pengujian perhitungan persentase keyakinan technical support terhadap solusi yang diberikan kepada pengguna aplikasi simplebiz adalah sebesar $89 \%$ dan tingkat keyakinan dari output yang dihasilkan oleh sistem terhadap kontribusi penyelesaian masalah tersebut adalah HAMPIR PASTI.

Berdasarkan hasil tersebut, maka juga membuktikan bahwa kombinasi metode forward chaining dan certanty factor sudah tepat dan HAMPIR PASTI dapat mengatasi dan menyelesaikan kendala yang dialami oleh pengguna aplikasi simplebiz, dimana metode forward chaining akan digunakan untuk menelusuri ciri-ciri kendala yang dialami oleh pengguna aplikasi simplebiz yang akan ditampilkan dalam bentuk pilihan-pilihan, sehingga sistem dapat memberikan solusi untuk kendala tersebut sesuai dengan basis pengetahuan (rule base) dari technical support, kemudian metode certainty factor akan digunakan untuk mendapatkan nilai keyakinan terhadap solusi yang telah diberikan oleh sistem.

\section{KESIMPULAN}

Berdasarkan pembahasan tersebut, dapat diambil kesimpulan bahwa rancang bangun sistem IT-helpdesk untuk maintenance dan tutorial aplikasi simplebiz menggunakan metode forward chaining dan certainty factor, dalam upaya membantu para technical support dari PT. Bamboomedia Cipta Persada dalam menangani kendala yang dialami oleh pengguna aplikasi simplebiz, dapat menjadi alternatif pemecahan masalah, diantaranya;

- Sistem IT-helpdesk untuk maintenance dan tutorial aplikasi simplebiz menggunakan metode forward chaining dan certainty factor dapat digunakan oleh para pengguna aplikasi simplebiz untuk berkonsultasi dan memperoleh solusi dari kendala yang dialami layaknya berkonsultasi secara langsung dengan seorang technical support, sehingga para pengguna aplikasi simplebiz dapat mengatasi kendala yang dialaminya secara mandiri. Berdasarkan hal tersebut, maka jumlah pengaduan yang diterima oleh para technical support baik secara bertatap muka, melalui telepon, SMS, maupun melalui aplikasi chat dapat berkurang. Selain itu, sistem IT-helpdesk untuk maintenance dan tutorial aplikasi simplebiz menggunakan metode forward chaining dan certainty factor ini juga dirancang berbasis responsive website untuk memudahkan para pengguna aplikasi simplebiz untuk mengakses sistem ini baik melalui desktop maupun mobile.

- Kombinasi metode forward chaining dan certanty factor dapat memberikan solusi yang akurat untuk mengatasi dan menyelesaikan kendala yang dialami oleh pengguna aplikasi simplebiz dengan alasan dan pertimbangan karena terbukti sangat cocok digunakan 
untuk sistem pakar atau sistem berbasis pengetahuan yang prosesnya dimulai dari pengumpulan data atau fakta, dimana metode forward chaining akan digunakan untuk menelusuri ciri-ciri kendala yang dialami oleh pengguna aplikasi simplebiz yang akan ditampilkan dalam bentuk pilihan-pilihan, sehingga sistem dapat memberikan solusi untuk kendala tersebut sesuai dengan basis pengetahuan (rule base) dari technical support, kemudian metode certainty factor akan digunakan untuk mendapatkan nilai keyakinan terhadap solusi yang telah diberikan oleh sistem. Hal ini juga dibuktikan melalui uji coba yang telah dilakukan pada penelitian ini, dimana berdasarkan hasil perhitungan persentase keyakinan technical support terhadap solusi yang diberikan kepada pengguna aplikasi simplebiz adalah sebesar $89 \%$ dan tingkat keyakinan dari output yang dihasilkan oleh sistem terhadap kontribusi penyelesaian masalah tersebut adalah HAMPIR PASTI. Berdasarkan hasil uji coba tersebut, maka telah membuktikan bahwa penerapan dan kombinasi metode forward chaining dan certainty factor pada sistem IThelpdesk untuk maintenance dan tutorial aplikasi simplebiz ini sudah tepat dan HAMPIR PASTI dapat mengatasi dan menyelesaikan kendala yang dialami oleh pengguna aplikasi simplebiz.

\section{REFERENSI}

[1] Nurul Chafid, Kiki Kusumawati, and Rosidiki Imami, “Analisis dan Perancangan Aplikasi Ticketing Pada Layanan Helpdesk ATM dengan Menggunakan Arsitektur 3 Tier,” Jurnal Satya Informatika, Vol. 2 No. 2, 2017.

[2] Evasaria M. Sipayung, Cut Fiarni, and Ernest Aditya, "Perancangan Sistem Informasi Helpdesk Menggunakan Framework ITIL V3. JNTETI,”Vol. 6, No. 2, 2017.

[3] Kasman Rukun, B.Herawan Hayadi, Isra Mouludi, Adyanata Lubis, Safril, and Jufri, "Diagnosis of Toddler Digestion Disorder using Forward Chaining Method,” 5th International Conference on Cyber and IT Service Management (CITSM), 2017.

[4] Mohammad Arifin, Slamin, and Windi Eka Yulia Retnani, "Penerapan Metode Certainty Factor Untuk Sistem Pakar Diagnosis Hama Dan Penyakit Pada Tanaman Tembakau,” BERKALA SAINSTEK, V (1): 21-28, 2017.

[5] Agus Irawan and Nanda Krisna Setiyorini, "Rancang Bangun Aplikasi Helpdesk Dengan Menggunakan Pendekatan Knowledge Management System Pada Seksi Teknisi pt. Indah kiat pulp \& paper tbk,” Jurnal ProTekInfo Vol. 4 Universitas Serang Jaya, 2017.

[6] Ali Mustopa, "Sistem Informasi IT-Helpdesk Pada Universitas AMIKOM Yogyakarta Berbasis Web,” Jurnal Informatika dan Komputer (JIKO) Vol. 2, No. 2, 2017.

[7] Delia Mediana and Andi Iwan Nurhidayat, "Rancang Bangun Aplikasi Helpdesk (A-Desk) Berbasis Web Menggunakan Framework Laravel (Studi Kasus di PDAM Surya Sembada Kota Surabaya),” Jurnal Manajemen Informatika. Volume 8 Nomor 02, 2018.

[8] Doddy Teguh Yuwono, Abdul Fadlil, and Sunardi, "Penerapan Metode Forward Chaining dan Certainty Factor Pada Sistem Pakar Diagnosa Hama Anggrek Coelogyne Pandurata,” Kumpulan Jurnal Ilmu Komputer (KLIK) Vol. 04, No. 02, 2017.

[9] Erlina Agustina, Istas Pratomo, Adhi Dharma Wibawa, and Sri Rahayu, "Expert System for Diagnosis Pests and Diseases of The Rice Plant using Forward Chaining and Certainty Factor Method," International Seminar on Intelligent Technology and Its Application, 2017.

[10] Indryani Astuti, Heri Sutarno, and Rasim, “The Expert System of Children's Digestive Tract Diseases Diagnostic using Combination of Forward Chaining and Certainty Factor Methods," 3rd International Conference on Science in Information Technology (ICSITech), 2017.
[11] Yeyi Gusla Nengsih and Nursaka Putra, "Sistem Pakar Menggunakan Forward Chaining dan Certainty Factor Untuk Diagnosa Kerusakan Smartphone,” Jurnal Sistem Informasi dan Manajemen STMIK GICI, Volume 8 No. 2, 2020.

[12] Fadlisyah, Risawandi, and Depi Elpina Tumanggor, "Sistem Pakar Diagnosa Penyakit Mata Menggunakan Metode Forward Chaining dan Certainty Factor,” Journal of Computer Science and Informatics Engineering (J-Cosine), 2020.

[13] Widya Lelisa Army, Yuhandri, and Sumijan, "Sistem Pakar Diagnosis Penyakit Menular Dengan Metode Forward Chaining dan Certainty Factor,” Research of Science and Informatic V4.I2 (171-181), 2018.

[14] M Ilham Aldyno, Sumijan, and Yuhandri, "Tingkat Akurasi dalam Mengidentifikasi Penyakit Telinga Menggunakan Metode Forward Chaining dan Certainty Factor," Jurnal Teknologi Dan Sistem Informasi Bisnis Vol. 2 No. 1, 2020.

[15] I Wayan Surya Pramana, Lie Jasa, “Analisis Penerapan Metode Forward Chaining Untuk Rekomendasi Instalasi Local Area Network (LAN) Menggunakan Pengujian System Usability Scale (SUS),” Majalah Ilmiah Teknologi Elektro Universitas Udayana, 2019.

[16] K. E. Setyaputri, A. Fadlil, and S. Sunardi, "Comparative Analysis of Certainty Factor Method and Bayes Probability Method on ENT Disease Expert System,” Scientific Journal of Informatics, vol. 5, no. 2, pp. 205-212, 2018.

[17] P. S. Ramadhan and U. F. S. Pane, “Analisis Perbandingan Metode (Certainty Factor, Dempster Shafer dan Teorema Bayes) untuk Mendiagnosa Penyakit Inflamasi Dermatitis Imun pada Anak,” Jurnal Sains Manajemen Informatika dan Komputer, vol. 17, no. 2, pp. 151157, 2018.

[18] Saiful Rizal, Rini Agustina, "Sistem Pakar Diagnosa Kerusakan Komputer Dengan Metode Forward Chaining Dan Certainty Factor Di Universitas Kanjuruhan Malang,” Jurnal Universitas Kanjuruhan Malang, 2015.

[19] I Kadek Dwi Gandika Supartha, Ida Nirmala Sari, "Sistem Pakar Diagnosa Awal Penyakit Kulit Pada Sapi Bali dengan Menggunakan Metode Forward Chaining dan Certainty Factor,” Jurnal Nasional Pendidikan Teknik Informatika (JANAPATI) Volume 3, Nomor 3, 2014.

[20] Abdul Wahaba, Akhmad Syahida, and Junaedib, "Penyajian Data Dalam Tabel Distribusi Frekuensi Dan Aplikasinya Pada Ilmu Pendidikan,” Education and Learning Journal, Universitas Muslim Indonesia, 2021.

I Gusti Ngurah Wira Partha: Rancang Bangun Sistem IT-Helpdesk... 